DOI: $10.1515 /$ hssr -2016-0012

\title{
The Schengen Space and the Primary Form of the European Legal Humanism. Revisiting Tony Honoré's Opus, Ulpianus. Pioneer of Human Rights*
}

Valeriu Ciucă ${ }^{* *}$

"Alexandru Ioan Cuza" University of Iasi, Romania

\begin{abstract}
The author proposes here "the first Romanian attempt at a hermeneutic systematization of the philosophy of European law", a field that is approached from an organic, integrating perspective. It has to be seen as a synchronic lectio magistralis on the ineluctable role of the spiritual roots when deciphering and assuming national identity. The complicated "euronomosophical" discourse, whose beginning is an excellent page of self-history about the "Europe" of the author, voices an appeal to a deeper self-knowledge. A complex, dynamic reality: from euromyth to euro-oniria and PaxEuropaea. Such incursions into the universe of law certainly involve an instructive and pedagogical side, building a patchwork of ideas, suggestions and themes that could be further developed.
\end{abstract}

Keywords

European law, "Euronomosophical" discourse, Legal humanism, Honoré

\footnotetext{
* This ad hoc session was also the subject of a lecture I was honored to deliver at "Petru Maior" University from Târgu Mureș in March 2016 in the framework of a collaboration with the Romanian Law Association and European Affairs and the Robertianum Center of European Private Law of "Alexandru Ioan Cuza" University from Iași.

** Faculty of Law, "Alexandru Ioan Cuza" University of Iasi, 11, bd. Carol I, 700506, Iasi, Romania; valerius_m_ciuca@yahoo.com
} 
HSS, vol. V, no. 2 (2016): 23-39

Motto: "Justitia est constans et perpetua voluntas ius suum cuique tribuendi. Iuris praecepta sunt haec: honeste vivere, alterum non laedere, suum cuique tribuere." (Domitius Ulpianus, Regulae, in Digesta, Liber primus, Titulus primus, $\int 1$ proemium ${ }^{1}$ )

In Justinian's Digest, the major part of the work which was generically referred to as Corpus juris civilis in the $6^{\text {th }}$ century (and which also comprises Imperatoris Justiniani Institutionum, Codex Justinianeus and Novellae constitutiones), over $40 \%$ of the content belongs to Domitius Ulpianus, a jurist of Syrian origin and Latin formation.

Not only the weight of Ulpian's texts, comments and notes in the general economy of the Justinian work made the British Romanist Anthony Maurice (Tony) Honoré - ex Regius Professor of Civil Law at Oxford University and a good collaborator of the law philosopher Herbert Lionel Adolphus Hart - dedicate the opus called Ulpian. Pioneer of Human Rights (Honoré, 2002), to the most important jurisprudent (philosopher of Roman law) of Antiquity.

The essential reason is deducted from the perennial nature of Ulpian commentaries, from their sagacity and philosophic and moral quality. Among the monographs dedicated by Honoré to certain famous Roman jurisprudents, such as Gaius and Tribonian, or the legal works created under the auspices of Emperors Theodosius and Justinian (codifiers of the Western and Eastern World, respectively), this monograph is by far one of the most brilliant on the Ulpian theme of the first European humanism that foresees the modern movement for human rights.

It is, as a matter of fact, a redundant theme of this author, who deals explicitly with the forms of palingenesis of the law (in its meaning of natural law and not positive law, such as in Emperor and Lawyers: with a palingenesia of third-century imperial rescripts 193-305 AD, published in London, in 1981).

\section{Topical European Justification}

I am inserting the present section, somewhat ad hoc, outside the initial strategy of treating Euronomosophy, out of my intention to briefly review Anthony Maurice (Tony) Honorés above mentioned work in order to 
capture the subtle historical link, on the canvas of the philosophy of law and of jus-naturalism, between Ulpian's thought and that of Stoic philosophers and jurists of the Roman Classical Age, namely the entire modern philosophy of the fundamental human rights, in a space of all liberties reserved, at a given moment, to nations.

On the other hand, there is also an anxiety, a disturbance that determines me to approach this subject under the form of a nonmethodical, free and ad hoc "review": namely, the increasingly more applied discussions during these years (2015-2016) on the possibility of "suspending the Schaengen Space", on this tentative to rebuild the isopoliteea (the "equal citizenship" (Honoré, 2002: 86)) of this symbol of European universalism and humanism, on the values of fundamental human rights and of magnanimously granted citizenship; an isopoliteea which needs to advance, for its own fulfillment, in simpoliteea or in the federalist spirit of the co-creation of European common legal norms, in ontological, principle-like meaning and not only in spontaneous amphictyonies.

For instance, if I think of Bessarabia, I have in view its perfect natural Europeanness, which predisposes it for the Schengen space. 27 March 1918 - one of Romania's and Europe's astral days. It is the day when the civilization arch of Romanism, from Chisinau to Lisbon, through the overwhelming vote of Sfatul Tării (the Country Council), rebound in the most natural manner. The natural justice brought Bessarabia home, in the Kingdom. Lupa Capitolina (in the photography in front of the Museum of Archeology and History from Chișinau), as well as at Rome, also came back home in its Romanian and European house of noble and beautiful Bessarabia.

The sum of the assertions above, partially, is what the Transylvanian, Romanian and other revolutionists from the Romanian Principalities in the $19^{\text {th }}$ century claimed, in perfect agreement with the European spirit, while being led by Simion Bărnuțiu and Alexandru Papiu-Ilarian (who would become founders of human law and natural law disciplines, saving the jus-naturalist spirit at the Faculty of Law from Iasi).

When I look at the chronology of the year 1848, an astral year for Europe, I have the mnemonic reflex of setting up a new spirit. PapiuIlarian holds a central space as a great mind-setter. 25 March 1848: in a historic, memorable speech at Târgu Mureș, Alexandru Papiu-Ilarian 
announces the fundamental principles of the Romanian Revolution from Transylvania, principles to be found in the other Romanian provinces later.

\section{Forma mentis civium Europaei.}

Attitudes, ways of European thought, mentalities and European civism...

... This is a part of analytical intentions and of certain benign, innocent exhortations revealed in a conference held at the headquarters of the historical Society of Doctors and Naturalists of the University from Iasi (the location of an important historical moment, since during the night of the $3^{\text {rd }}$ of January 1859, in its meeting room, the deputies of the National Party of Moldova decided to support Al. I. Cuza candidacy to the throne), a conference I was invited to by my most affine master, Professor Doctor Docent Marțian Cotrău (1923, Fiziș, Beiuș - “Samuil Vulcan”, Iași, 1998), 22 years ago. Its mood was then very philo-European in all its political, institutional, cultural, spiritual, legal and philosophical dimensions.

Professor Marțian Cotrău, who dreamt of becoming a jurist in his adolescence (a dream forbidden by the dictatorship of the proletariat in its full emergence) a symbol of erudition and encyclopedic spirit of Iasi, was particularly attached to the European idea and adopted, by faith and culture, a very natural philo-European position in Romania, at the dawn of the democratic existence of this country, after the aurora-like rebirth from the deadly sleep of the Communist dictatorship.

On a social media page mostly open for my disciples, I would write, in memoriam, the following: "07.IV.1998. The heavens receive my dear spiritual master, Marțian Cotrău. It is a special moment, of redemption and peace. The time of his life was full of sacrifices for his people, for his state, for the Crown and for his science. Iasi has lost, in real time, an adoptive son, forsaken by tenebrous and criminal times, but has won a symbol of renaissance, encyclopedic spirit and flawless Christian spirituality, a symbol of excellence and unconditional love, of perfection: a spirit that still remains, after 18 years, unmatched. Requiescat in pace!"

It is to him that I dedicate the following lines written in connection to Anthony Honoré's work.

The ideas expressed at the time have, in this context of Euronomosophy, a pure propedeutical role; they prefacing the subtle 
connection, the integration of the most important leap of the universal history of law by means of Constitutio Antoniniana (which authorized the Roman citizenship of all the inhabitants of the Roman Empire, except for the deditic peregrines), to the impressive juridical phenomenon triggered by the 1789 proclamation of the Universal Declaration of the Rights of Man and of the Citizen, and to the particular normative architecture, transformed in the jus-naturalist vector of these rights in Europe, the architecture of the so-called Schengen Space.

\section{The Cosmopolis and Human Rights.}

\section{In what spirit do we approach the act of justice in Europe?}

The end of the first section is surprising for a jurist who is not initiated at least in the secrets of a religion: one cannot approach the law "with unwashed hands" or, as Gaius used to say (Digesta, 1.2.1; Gaius 1 ad 1. XII tab.) with reference to the Law of the XII Tables (Lex duodecim tabularum) (Honoré, 2002: 77 et sq), without exordium, without "prefacing" as a synonym for the symbol of initiation, both "religious", as well as for the sacred art of the law (the ritual washing of the hands: Tora); this vision is also shared by Seneca and Cicero ("the cult of justice" - justitiam colimus).

Jurists, according to Ulpian, are the "priests of the law" (Institutiones, a sort of a manual for students, on Gaius' model). The concept of the sacred nature of law is reused in another text, De omnibus Tribunalibus, liber I-X, addressed to practitioners used to the interpretative techniques for the art of "good" and "equity", which is the law. That is why, Ulpian argues, the professors of law, as well as the priests, should not charge money for their gift if they are not paid, bene volentia, by the disciples...

In another interpretative formula, the cult of justice and of the good, of "the use", one can also find the Romanian philosopher and jurist Vasile Conta, who underlines the concept of justice, in quite a paralogical manner for a materialist, as a product of intuition, of "social instinct." 3 This makes reference, as a matter of fact, to the same stoical idea of "cult", of justitiam collimus. Mention should be made of the fact that the European concept of rule of law fails to refer to the purpose in itself but to justice by the force of law.

Only justice, equity (aequitas) represents a purpose in itself, being the greatest value that generates human law (buman rights), besides liberty 
(libertas) and dignity (dignitas). In other words, on a stoic model marked by laic, humanistic sacredness, and of course, symbolically, we should wash our hands in a ritual when we open the book of supreme legal values of the European Union. In other words, we should have a reverential spirit marked by respect for the bi-millennial sacrifices that accompanied, on the altar of these values, the history of the configuration of the European set of norms with identity, as a supreme value.

In what spirit does Ulpian dedicate himself to art, science and the cult of law? In the spirit originating in his juridical philosophy: universalism and equity, a philosophy that "lays its print" on the European dream in Jeremy Rifkin's socio-juridical meaning

This Honorian thesis in the subtitle is also supported by William L. Burdick (1939) - The Principles of Roman Law and their Relation to Modern Law.

After Antoninus Caracalla's Constitutio Antoniniana (212 p.Cr.), Ulpianus exposes law as a "universal good, for free, equal and dignified peoples".

These three values (liberty, equality and dignity) are at the basis of the entire ideology of human rights, as its ontological part and Ulpian is their first pioneer. The legal form, the action that protects them in front of the judge is actio injuriarum (which had become a common action for the personal, social and economic rights violated by anyone) (Honoré, 2002: 85).

Physically and psychically, people need to be protected because they have to defend human dignity. Even today, the fundamentals of civil rights are still found in "liberty, equality and dignity"(Honoré, 2002: 90).

$\mathrm{He}$ is an apologist of Caracalla's Edict from 212 p.Cr. (Constitutio Antoniniana). This document comprises the most generous authorization of Roman citizenship, the most magnanimous legal act, for its "humanitarian" character, one of assimilation of the barbaric people from the empire (except the Deditics) to the Roman citizens, both with regard to public and private rights and with regard to civil obligations (tributum sive impositum \& bereditatem publicanus \& servitium militare).

In this context, I find it a good opportunity to mention the profound prudential economic philosophy of Vespasian in relation to the size of taxes, state levies of any kinds that should be paid by citizens, a legal and philosophical vision that is synthesized in the everlasting apoftegmatic 
formula: Boni pastoris esse tondere pecus, non deglubere... (To be a good shepherd is to shear sheep, not to flay them).

\section{Jus naturalis in Europe, or the good preface to the principle of "indivisibility" in the universe. Its product - the ideal law and the ideal of law - concentrated in the everlasting formula: Jus est ars boni et aequi}

To separate oneself from the rest and return to divinity, one needs to proceed saintly, carefully towards the Creation... If you cannot do it, it's better not to be separated and to forget about the "Be fruitful and multiply; fill the earth and subdue it" (Genesis, I. 28).

In essence, this is what jus-naturalists claim: a behavior in harmony with nature, respecting the nature of things and of human nature without separating them from the rest of nature, and agreeing with universal and equitable moral principles.

The jus-naturalist definition of law, somewhat different from Dura lex sed lex (paradoxically, another Ulpian hermeneutical formula...) was supported for the first time by the jurisconsult of the Classical Age, Celsus, being used again after a century by Ulpian and then by a Julius Paulus (the second author according to the number of quotations in Justinian's Digests.

The famous Celsian definition, appreciated by Ulpian, had echoes in medicine. Tony Honoré makes an interesting comparison with Galenus' definition of medicine (Claudius Galenus from Pergam), a contemporary of Ulpian. For him, medicine was an art of the good and utility, similar to law, detached from superstitions and ignorance, doctors needing philosophical training (as Cicero claimed for jurists; this is my exhortation as well), theoretical training based on science, logic and contempt towards getting rich. Everything to set as long a distance as possible from the spectrum of imposture.

Medicine, like law, has reason (habet rationem). Its primary philosophy, as a particular art, is its scientific nature, as in legal hermeneutics. Without "incantations, imprecations and exorcisms", as Ulpianus writes in Digests. ${ }^{4}$

Thus, indirectly, one creates bridges of comprehension of utility, of the good, in perfect proximity with law and justice; reason is no longer counter-set to free will as long as it does not harm a third party, as long as it is not harmful and observes the regula aurea (still of stoic and Ulpian 
origin: alterum non laedere...). This is a good finding of our jurist and philosopher from Iasi, Vasile Conta, becoming an object of quoting, of simple reasoning in the pages of the book signed by H. Spencer, Sociology. 5

Ulpian asserts the force of natural law as a means to re-anchor law in a moral order (usurped in time by sophists, proving that Plato's warnings had not been vane). This moral evanescence of the law had come to justify irrational, inacceptable solutions, born out of a traditionalist legal formalism in its bad, non-consuetudinary and non-common law meaning.

Jurists of the end of the Golden Age dreamt of new, philosophical and moral, i.e. Humanistic bases for law. Even theologians, led by Origen, dreamt of a philosophical interpretation of Christian thought, at exactly the same age.

What would be the use of a medicine of hypocrite charlatanisms, a legalist-formalist law, be it a "traditionalist-sophist" one of injustice and a theology of man's abandonment and alienation? This must be how Ulpian thought, judging from his jurisprudential texts (of law philosophy). The author reviewed here tells us, in fact, the same thing, talking about Ulpian's propensity for the useful, rational and honest law, qualities of the moral and humanist law which will set the bases of the theory of fundamental human rights in the rationalist age of Enlightenment. Libertas est naturalis facultas... Servitus est ... contra naturam... (Florentinus; Ulpian et Paulus will resume these definitions and will account them for the natural and common law of all people, being obvious that jus civile knows positivist limits)(Honoré, 2002: 88).

What determines for us, jurists, moral orientation is not so much a philosophical school but the edifice of legal values with which we perceive the world's reality. Stoicism (Stoa) with its three Ciceronian constants (born free $^{6}$, equal and in harmony with the nature $)^{7}$ from Ulpian's thought forges a type of reflection that leads us to human rights along the gold pavement of the religious tradition.

Ulpian, for instance, is the first to immortalize the exhortation that has become assent under oath for marriage 8 and which doubles the mystical metaphor of the union of two people into one ${ }^{9}$, with the synalagmatic coresponsibility of equally distributing good and evil (from the natural equity aequitas)(Honoré, 2002: 93, note 160), a new philosophical legal conception 
which was acculturated to us, through Justinian's work, in the Church and later in European law ${ }^{10}$. Exempli gratia:

Groom: I take you to be my wife. I promise to be true in good times and in bad, in sickness and in health. I will love you and honor you all the days of my life

Bride: I take you to be my lawfully wedded husband. I promise to be true in good times and in bad, in sickness and in health. I will love you and honor you all the days of my life.

This stoicism is less interesting today, unfortunately, than the open humanism to the universality of the fundamental human rights (which, unfortunately, are relative in the civilization conflicts from the boundaries of Europe).

The world, by reason of the law that reproduces a part of the common reasoning (Marcus Aurelius) may become a sort of cives communis. The world, with everything it stands for, should obey the law (avant la lettre, the rule of law, consecrated by Chryssipus, the head of the stoic school, after the jurisprudent Aelius Marcianus, Ulpian's disciple).

Or, on the other hand, the equality of citizens under the government of the same law can only be beneficial, useful, practical and profitable for all, for all categories: travelers, sailors, traders, bankers, craftsmen, magistrates, judges (who thus see their decisions applied all over the empire), etc., Domitius Ulpianus refers to this all in numerous texts saved by the Justinian Pandectae ${ }^{11}$.

In Ulpian terms, knowingly or not, in the past but especially in the present times, thus speak to us the political, economic and social analysts who defend the principles of the Citizens' Space of formal and real equality of the Schaengen type...

\section{Demystifying the law-basis of human rights in the European Union = extension of the "jus Flavianum" paradigm}

Domitius Ulpianus, expanding Gaius's conception and Cicero's thesis (jurists who develop a cult of justice - justitiam colimus), urges jurists to create solutions that are "accessible to human reason" (Honoré, 2002: 84).

Ulpian was a vector of the granting of Roman citizenship to all 
inhabitants of the Empire, together with other contemporary humanist jurists (Aelius Marcianus, his disciple, or Julius Paulus, influenced by Julia Domna's literary circle, a "mother of the country" (Blaise, 1990: 238) or by Papinian, with Quaestiones et responsa, where law is a fundament of humanism ...).

All those mentioned above were living vectors of Caracalla's Edict (Constitutio Antoniniana), the most generous legal act ever recorded in the universal history of law. It is the founding document of a Cosmopolis that defeats, symbolically, the Empire..., with consequences even on thesis of the equality of languages in the Empire, with the abandonment of monopoly of Latin and Greek. ${ }^{12}$

In his writings, Ulpian the cosmopolite ${ }^{13}$ also stands out, in fact, through the use of the largest number of quotations from the Greek philosophy in the Greek language. (Honoré, 2002: 91)

We realize now the dimension of the ridicule simulated by the visceral nature accompanying the "suspension of the Schengen space" in relation to Constitutio Antoniniana...

One could retort saying that 2016 is not a "peaceful" year. But, at a deeper analysis, we see that 212 p.Cr. was not peaceful at all: it suffices to evoke the fratricide against Geta (at exactly one year - in February - since the death of the father, Septimius Severus), accompanied by bloody repressions led by Caracalla, with thousands of victims in Rome (among whom Aemilius Papinianus); maybe we should also mention the profound hatred of the Senate towards Caracalla, a terrible hatred that explains the trivialization of the reasons for granting citizenship to all those free people in the empire; but, if we mention the Senate's hatred, let us not ignore the deep love of Julia Domna, former councilor of Caracalla, the center of gravity of the Roman intellectual and spiritual elites (permeable to the philosophical influences in law) (Honoré, 2002: 91), who died in "hunger strike" after the murder of Caracalla, following a plot...

The Schengen Philosophy, as noticed before in the intellectual exercise focused on jus-naturalism, stoicism, Roman classicism and distilled by Tony Honoré's work that we have reviewed, is a legal philosophy that focuses on some of the most noble legal values and human ideals, such as: a real state of unity, not merely at a level of proclamation of the European Union's peoples, a condition reinforced by facilitating the free circulation 
of people, capitals and services; the state of solidarity through liberty, that implies an exemplary goodwill, so that what was the natural prerogative of a country's individual (the use of that territory) has become, by defeating all paradoxes, res communis by reciprocity; at last, the state of politico-juridical will shared and fixed on a common ideal: the suppression of natural historic obstacles and artificial - historic ones hindering the free circulation (in general-human meaning), in agreement with the need to ensure an efficient vector of the fundamental human rights in the European area. The European society thus becomes, through the Schengen philosophy, a Schengen Union, a union in which there are only minorities, being neither a garrison, nor a memory of clusium, nor Leviathan or the memory of Empire.

The Schengen philosophy transforms the space of tolerance (tollere=permittere $=$ report, of power still: someone tolerates, someone is tolerated) (Ciucă and Ciucă, 1996: 507 sqq) in a space of co-government and legal co-creation, of sympoliteea, in which not even izopoliteia is not enough.

By federalizing families, one does not tolerate them; the same applies in case of nations permanently under the cult of necessary, rational fraternity among equals (amphictions), not between the big brother, middle and little one. In the Schengen philosophy, tolerance is not an ideal, but just a pavement to the ideal of federalization of differentiated citizenships into an undifferentiated one.

The Schengen philosophy is facilitated by the border people's mentality: Europe's parents were people of the frontier; especially Robert Schuman, whose father, Jean-Pierre Schuman came from Evrange, where there are the tombs of paternal grandparents, of his forerunners: you enter the gate of Saint Albin's churchyard in France and, if you jump over its fence, you reach Luxembourg..., in Frisange village, in its turn in the vicinity of Bettemburg commune, the birthplace of his beloved mother, Eugénie Duren. It is the frontier on which an edifice of good and relaxation was built, "L'Hotêl-restaurant de la frontière", right at the intersection that unites more than separates the two countries....

A theme of meditation in the perimeter of Schengen philosophy is also the image of a "frontier" that "sews" and not "unsews" the territory dedicated to the entertainment of the public, between Belgium and Holland. If we 
could imagine, until the full union, a Romanian "Schengen," we would probably use the sublime image of the localities crossed by a river, while preserving their natural organic nature: for instance, Sculeni or Unghenii Iasului that awake in me the meditative spirit of the paradoxical centricity of the frontier.

The spirit of Schengen was not born in 1985 on June 14, when the approval of the five initiating countries (France, Federal Germany and Benelux: Belgium, Luxembourg and Netherlands; see Addendum X, at the end of the book $)^{14}$, transformed in the Convention signed on 19.06.199015 and enforced on the $26^{\text {th }}$ of March 1995. It was integrated as acquis Schengen, a con-substantial part of the communitarian acquis of the Council, through Decision 435 from 20 May 1999, right after the Amsterdam Treaty was in force, subsequently sanctioned for good as a space of the free circulation by Directive CE no. 38 of the Council and European Parliament in the grace year 2004 (the year of Romania's accession to NATO and of its acceptance in the EU, under the benefice of reform, with a symbolic absolution of approximately three years in relation to the "Eastern bloc" of the Union).

It is a profound philosophy, present in the spirits of its founders at the very first moments of the Communities ("The Treaty of establishing the European Communities", completed by the Single European Act, stipulated that the internal market should comprise a space without interior frontiers, according to the Convention from 1990, quoted above). It is, in fact, the very reason of the Union's existence and, at the same time, the warranty of its functioning as a space of liberty and justice, of equity among European citizens; it is also a palisade, a warrant of the fundamental rights which cannot be interpreted locally.

The European Union is not compatible with interior fences, its refuge for the reason, spirit and legal humanism being against dislocation, ghettos and disintegration. The refugees of today do not jeopardize the suspension of the Schengen philosophy; certain Europeans, in a spirit of "marquis", ignore the fact that the "dukes", their equals from the kingdom's external borders, are co-responsible for the whole, by strengthening these borders against irregularities, not against desperate people looking to survive in a world, be it exterior, extra/European, but engulfed in the frenzy of war...

Crises, it is said, and this is already a truism, served Europe well; each 
time, its legal philosophy came out better crystallized. The present one is yet another chance, especially given its reductionist and manipulating image; if, after an exercise of the imagination, we concentrated all the travelers from the Union's airports in a single one, let's say Frankfurt, we would have a much more overwhelming image of the human influx than what we can see near the improvised fences erected against the natural right of passage... Dum spiro spero, as Cicero used to say.

Out of these states and relationships, out of this magma of free attitudes, one can extract (by sublimating the idea of value and legal principle) the contents of the European law. It is an autopoiesis which suggests to me the most complex operation of individual and collective "divination" which would be the European law per se; an European law in itself like a conservatory bridge towards the common European future, against even the activist voluntarism fatalist unforeseeable nature or volatility or the caprice of personal or group histories.

Through this ambivalence, a law that preserves and a law that is selfcreated in Ciceronian spirit, "divine-like", the European law acquires an "amphibian" role (paraphrasing Annick de Suzenelle), a Gnostic one (of knowledge through passion), of reconciliation of the conscious with the unconscious (projection of a quasi-revelation), all under the sign of love and a universal prestige (universali fama sive auctoritatis; omnis rerum claritas) deriving from the common project devised by Robert Schuman through his famous Declaration from May 9, 1950.

The creation of Europe thus appears to us as a continuum, in which we, the contemporaries, are present at the Opera as its instruments, not only as its beneficiaries.

On the particular plan of the liberty of travel and work, we can decrypt the European vision from the very complex Interpretative Communication of the European Commission, from July 13, 2010, which systemizes the definitions and exceptions established along the time by the European jurisprudences we meditated on above, when we called attention to the limitative interpretations of exceptions, under the influence of the principles generated by the Roman law (Exceptio est strictissimae interpretationis, respectively, Exceptio firmat regulam in casibus non exceptiis).

Well, well, master and $\mathrm{PhD}$ students will wonder, since the interpretative communications are not reputed as formal sources of the 
HSS, vol. V, no. 2 (2016): 23-39

European law, why would we invoke them? Are they not, ipso facto, simple means of cognoscibility of European norms, common means among other ordinary means? In other words, aren't these interpretative communications anything else but simple real sources of European law, like the particular sciences, epistemologies and interpretative habits on the national plan?

Before anything else, though, theora, under the form of an explicative codicil, as if it were a hermeneutic intermezzo by the side of an interpretative instrument of legal culture...

\section{References}

Blaise, A. (1990). (direction éditoriale) et. Al. Chronique de l'bumanité. Paris : Ed. Chronique, Ed. Jacques Legrand S.A.

Chindris, I. (2002) Ideologia revolutionară a lui Alexandru Papiu Ilarian. Bucuresti: Ed. România Press.

Cicero, M. T. De finibus

Ciucă, V. M., Ciucă, A. (1996). "Un possible paradigme juridique pour les minorites réligieuses en Roumanie, oeuvre d'une acculturation juridique". Actas del III Congreso "Cultura Europea". Centro de Documentacion Europea. Universidad de Navarra. Pamplona: Edit. Aranzadi S.A.

Conta, V. (1967). Opere filosofice. Ediție îngrijită de N. Gogoneață, Bucuresti: Ed. Academiei.

Honoré, A. M. (2002). Ulpian, Pioneer of Human Rights. Second edition. Oxford: Oxford University Press. (Editio princeps, 1982).

Ulpianus, D. Digesta. Liber L (Libri ad Sabinum)

Ulpianus, D. Digesta, Liber XXIV (Libri ad Edictum)

Ulpianus, D. Digesta, Liber VIII, De omnibus Tribunalibus

The Ancient Testament, Genesis

\footnotetext{
1 "Justice is the constant and perpetual will to give to each individual what they deserve. The principles of law are the following: live honorably, not harm the other, give everyone what they deserve."

${ }^{2}$ http://muzeuistoriafarmaciei.ro/cotrau-iasi/, 07.IV.2016.

${ }^{3}$ Vasile Conta, Insemnări, în N. Gogonoață, op. cit., p. 615: "Sentimentul justiției este presimțirea folosului. Folosul (utilitatea) este conștiința deplină despre acțiunile conservatoare. Iată de ce utilitatea caracterizează societățile înaintate. La început, societățile istorice făceau prin instinct lucrurile ce toți (le commun des mortels) le găsesc acum folositoare. Acum sentimentul justiției este un
} 
instinct. Nu avem încă cunoștință deplină de acțiunile juste, fiindcă reprezintă o utilitate foarte complicată care nu poate încă fi îțeleasă decât de inteligențe foarte puternice" (The sentiment of justice is the intuition of use. The use (utility) is the full consciousness of conservative actions. This is why utility characterises advanced societies. In the beginning, historical societies performed instinctively things which everybody (le commun des mortels) now finds useful. Now the sentiment of justice is an instinct. We do not have yet a full consciousness of just actions, becaue they represent a very complicated utility that can only be understood by very strong intelligences").

${ }^{4}$ Domitius Ulpianus. Digesta. Liber L. Titulus XIII. 1.3 (Liber VIII, De omnibus Tribunalibus: "De medicis: Medicos fortassis quis accipiet etiam eos qui alicujus partis vel certi doloris sanitatem pollicentur ut puta si au si fistulae vel dentium: Non tamen si incantavit imprecatus est si ut vulgari verbo impostorum $i$ utar non sunt ista medicinae genera tametsi sint qui sibi promisse cum praedicatione adfirment", apud T. Honoré. op. cit. p. 78. note 20.

${ }^{5}$ Note on Vasile Conta's copy of H. Spencer. Sociologie. apud N. Gogoneață. op. cit. 632.

${ }^{6}$ D. Ulpianus. Digesta. Liber L. Titulus XVII. 32 (Libri ad Sabinum). apud T. Honoré. op. cit., p. 81, note 43.

${ }^{7}$ Marcus Tullius Cicero. De finibus. IV. 14: convenienter naturae vivere. apud T. Honoré. op. cit. p. 80. note 36.

8 Domitius Ulpianus. Digesta. Liber XXIV. Titulus tertius. 22.7 (Libri ad Edictum): quid enim tam humanum est, quam ut fortuitis casibus mulieris maritum vel uxorem viri participem esse?. cf. Swain (1996) 119f. apud T. Honoré. op. cit.. p. 81. note 44.

${ }^{9}$ Old Testament. Genesis. 2. 18: "It is not good that the man should be alone. I will make him a helper meet for him"; Genesis. 2. 24: "Therefore shall a man leave his father and his mother, and shall cleave unto his wife; and they shall be one flesh."

10 Nemo debet aliena jactura locupletari: No one needs to win the other's loss... Benefit and loss go"hand in hand", in order to avoid the exploitation of the ignorant, the unlucky, the credulous etc. (Dig.. Lib. XIV. Tit. III. 1 (Ulpianus. 28 ad Edictum). apud A.M. Honoré. op. cit.. p. 93. note 162. At the same time, in the meaning of the current European jurisprudence, similar situations call for similar solutions and the conflict situations call different solutions. One does not apply different solutions to similar conflict situations nor similar solutions to different conflict situations.

${ }^{11}$ A. M. Honoré, op. cit., p. 93, notele 148, 149 et sq.

${ }^{12}$ Digesta, Liber XIV, Titulus tertius, 11.3 (28 Ulpian ad Edictum: litteris itrum 
Graecis an Latinis?), apud A.M. Honoré, op. cit., p. 89, note 114.

${ }^{13}$ Ulpian is a Roman citizen jurisprudent, born in a family of ethnic origins - or at least destiny, existential, cultural ones - in the cosmopolitan Tyr (in the South Eeastern part of today's Lebanon, in the former purple Fenicia. This was the land of Purple Phoenix and Queen Telephasa, a kingdom which, through the princess kidnapped by Jupiter, metamorphosed as Taurus, at the suggestion of Hermes-Mercurius, gave us Europe, sheltered then in the future MinoicCretan civilization).

14 «Accord entre les Gouvernements des États de l'Union économique Benelux, de la République fédérale d'Allemagne et de la République française relatif à la suppression graduelle des contrôles aux frontières communes, signé à Schengen le 14 juin 1985 Les Gouvernements du Royaume de Belgique, de La République Fédérale d'Allemagne, de La République Française, du GrandDuché de Luxembourg et du Royaume des Pays-Bas, ci-après dénommés les Parties"(http://www.senat.fr/europe/acquis_schengen_1999.pdf).

15 "The Convention for the enforcement of the Schengen Agreement from June 14, 1985 between the governments of the states in the Benelux Economic Union, the Federal Republic of Germany and of the French Republic regarding the gradual elimination of controls at the common frontiers: the Kingdom of Belgium, the Federal Republic of Germany, the Grand Duke of Luxembourg and the Netherlands, hereinafter referred to as 'contracting parties', / Based on the Schengen Agreement from June 14, 1985 regarding the gradual elimination of controls at the common frontiers / Determined to enforce the decision expressed herein to eliminate the controls at their common frontiers on the circulation of people and to facilitate the transport and circulation of goods at these frontiers / As the founding treaty of the European communities, completed with the Single European Act stipulate that the internal market should comprise a space without internal borders (my italics.), / As the purpose of the contracting parties is in agreement with this objective, without prejudice to the measures to be adopted in view of enforcing the dispositions of the treaty , / As the enforcement of this decision requires a series of actions and close cooperation between the contracting parties / Agree as follows:" (http://eur-lex.europa.eu/legal-content/RO/TXT/HTML/?uri=CELEX: 42000A0922(02)\& from $=F R$ ) 
HSS, vol. V, no. 2 (2016): 23-39

\section{Biographical note}

Valerius M. Ciucă (born 1960) is a Professor PhD of Roman law, Private comparative law and Philosophy of European law, PhD. supervisor at the Faculty of Law of "Alexandru Ioan Cuza" University of Iaşi, Associate Professor at ULCO, Lab. RII, France, invited professor at the University of Ottawa, Canada, ex-judge of the European Union Court, founding member of "Petre Andrei" Academic Foundation from Iaşi, of "Robertianum" Center of private European law of "Al. I. Cuza" University from Iaşi, of the Circle of juridical hermeneutics "The School of Organic Law", of the Center of Legal Research "The Exegetic School after the Method of Post-glossaries"; scholarship owner of the French Government, of the American Bar Association and the Jagellonian University of Cracow, of the European Council and the European Law Academy from Florence, of the International Law Institute, pendant of Georgetown University, Washington etc. for research stages; member of academic, research and philanthropic societies from Romania and abroad. Supreme Distinction: Professor Bologna of year 2015, granted by the National Alliance of the Students' Organizations of Romania. He is the author of numerous books and articles in his fields of interest. 